\title{
Carbon stock assessment using forest canopy density mapper in agroforestry land in Berau, East Kalimantan, Indonesia
}

\author{
ADISTI PERMATASARI PUTRI HARTOYO ${ }^{1, \bullet}$, LILIK B. PRASETYO ${ }^{2, \bullet \bullet}$, ISKANDAR Z. SIREGAR $^{1}$, \\ SUPRIY ANTO $^{1}$, IDA THEILADE ${ }^{3, v \vee v}$, ULFAH J. SIREGAR ${ }^{1}$ \\ ${ }^{1}$ Department of Silviculture, Faculty of Forestry, Institut Pertanian Bogor. Jl. Lingkar Akademik, Dramaga, Bogor 16680, West Java, Indonesia. \\ Tel./fax.: +62-251-862-6806, `email: adistipermatasari@apps.ipb.ac.id \\ ${ }^{2}$ Department of Forest Conservation and Ecotourism, Faculty of Forestry, Institut Pertanian Bogor. Jl. Lingkar Akademik, Dramaga, Bogor 16680, West \\ Java, Indonesia. Tel.: +62-251-862-1677, Fax.: +62-251-862-1256, ^vemail: lbprastdp@yahoo.com \\ ${ }^{3}$ Department of Food and Resource Economics, University of Copenhagen, Rolighedsvej 25, 1958 Frb. C, Bygning B, 1. Sal, Denmark. \\ •vemail: idat@ifro.ku.dk
}

Manuscript received: 23 June 2019. Revision accepted: 26 August 2019.

\begin{abstract}
Hartoyo APP, Prasetyo LB, Siregar IZ, Supriyanto, Theilade I, Siregar UJ. 2019. Carbon stock assessment using forest canopy density mapper in agroforestry land in Berau, East Kalimantan, Indonesia. Biodiversitas 20: 2661-2676. In the Reducing Emissions from Deforestation and forest Degradation (REDD+) program, remote sensing is the most important tool for measuring forest cover and carbon dynamic, including the utilization of software Forest Canopy Density (FCD) mapper. However, there have been rarely untested the accuracy of FCD applied in agroforestry landscapes to support carbon stock assessment compared to conventional field measurement data. This research was aimed to investigate the correlation between: (i) the value of FCD (\%) and tree stand density (N/ha), (ii) the value of FCD (\%) and basal area $\left(\mathrm{m}^{2} / \mathrm{ha}\right)$, (iii) the value of FCD (\%) and total carbon stock (Mg C/ha), and iv) total carbon stock and percentage of canopy closure $(\%)$. Tree stand density, basal area, carbon stock and canopy profile were conventionally measured by trained members of local communities. The results of this study showed that the $\mathrm{R}^{2}$ between FCD and tree density was $37.7 \%(\mathrm{r}=61.4 \%)$, while the $\mathrm{R}^{2}$ between FCD and the basal area was 3.33\% $(\mathrm{r}=18.3 \%)$. The result of normality and heteroscedasticity tests showed that FCD was more accurate and precise in estimating the tree stand density model than the basal area model. Total carbon stock differed significantly $(\mathrm{p}<0.1)$ from tree density with $\mathrm{R}^{2}=27.7 \%(\mathrm{r}=27.3 \%)$. Total carbon can be predicted using FCD with total carbon $(\mathrm{Mg} \mathrm{C} / \mathrm{ha})=13.005+0.826 \mathrm{FCD}$. Our findings suggest that FCD can be used as a new method to estimate tree density and total carbon stock cheaply, efficiently and accurately to support carbon stock assessment in agroforest practices. In carbon assess ment, total carbon stock can also be estimated using canopy closure measurement.
\end{abstract}

Keywords: Carbon stock, forest canopy density mapper, REDD+, remote sensing

\section{INTRODUCTION}

The implementation of Reducing Emissions from Deforestation and forest Degradation (REDD+) in Indonesia requires the inclusion of following aspects: the National Strategy of REDD+, the baseline of Forest Reference Level (FRL) or Forest Reference Emission Level (FREL), the system for Measuring, Reporting, Verifying (MRV) and National Forest Monitoring Systems (NFMS), Financial Instruments, Safeguards and REDD+ Safeguard Information System, as well as National Registration System (NRS). The National Forest Monitoring System (NFMS) transparently provides forest resources data and information related to Indonesian forests, as well as consistently contributes to the development of Measuring, Reporting, Verifying (MRV) system to support mitigation action at the national and subnational level (Regulation of Indonesia Ministry of Environmental and Forestry 2017).

Currently, there are three approaches to estimate or monitor biomass, namely mathematical modeling, field measurement and remote sensing. Of the three approaches, field measurement has been considered as the most accurate and precise method than the other approaches. However, this approach is expensive and has limitation in covering large area, particularly for remote areas with difficult access. As such, remote sensing is considered as the most important tool for measuring reference levels and monitoring the dynamics of carbon in the future (IPCC 2006).

For decades, remote sensing has been a powerful tool in biodiversity conservation issues as an effective means to collect data and information at a large scale especially in forest and biodiversity monitoring (Turner et al. 2003; Boyd et al. 2005; Duro et al. 2007; Strand et al. 2007). Similarly, in carbon monitoring activities, remote sensing could be used to produce data needed, but this should be complemented by ground-truthing activities in certain areas in order to obtain valid and accurate information (Strand et al. 2007). For large-scale reforestation and rehabilitation efforts, remote sensing is regarded as the most optimal method, despite the level of accuracy for this approach is being potentially lower than that of field measurement (Ardiansyah et al. 2005).

In developing countries, remote sensing using satellite imagery is the only effective method for covering and monitoring large forest areas at a national-level (De Fries et al. 
2007; Bottcher et al. 2009; Goetz 2009). The identification of land cover can be done quickly, cheaply and frequently using remote sensing. According to Budiharta et al. (2014), the total budget needed to restore 6.1 million hectares forest estate land (excluding industrial timber plantation) in East Kalimantan needs approximately US\$ 8.37 billion. If we use remote sensing, it will be cheaper. Furthermore, remote sensing for estimating forest density has been successfully used to assess forest degradation (Tiwari et al. 1986; Prince et al. 1987; Ford et al. 1988).

Forest canopy density describing the physiognomic characteristics of forest can serve an important parameter for the characterization of forest condition. Several approaches for mapping forest canopy include object based classification (Dorren et al. 2003), artificial neural network (Boyd et al. 2002), linear regression (Iverson et al. 1989; Zhu and Evans 1994; De Fries et al. 1997), decision tree classification (Souza et al. 2003), spectral unmixing at pixel or subpixel scale (Gao et al. 2000; Gong et al. 1994), the application of Maximum Likelihood Classification (MLC) and Multiple Linear Regression (MLR), as well as forest canopy density mapper (FCD) (Rikimaru 1996). However, some remote sensing methods, for example, NDVI (Normalized Difference Vegetation Index), have limitations for identifying land cover since several parameters are not taken into consideration including those related to thermal, bare soil and shadow. Similarly, the application of MLC and MLR to measure forest canopy density is based only on spectral reflectance of vegetation.

Considering that vegetation index alone is not enough to get precise and optimal results in estimating forest canopy density in tropical mixed deciduous vegetation (Rikimaru and Miyatake 1997), forest canopy density (FCD) mapper as a semi-expert system of a computer software package is likely compatible and suitable with the window-based personal computer. The FCD mapper consists of algorithms and formulas utilized to compute values by taking into consideration of vegetation, thermal, shadow and bare soil index using satellite imagery data.

This study was aimed to investigate the application of FCD in carbon stock assessment to enrich knowledge developed by many existing studies related to forest cover assessment using satellite images, for example Rikimaru (1996), Rikimaru and Miyatake (1997), Baynes (2007), Joshi et al. (2005), Panta et al. (2006), Prasad et al. (2009) and Mon et al. (2010). Tree stand density, basal area, and forest canopy profile are commonly used as parameters to measure forest density and forest vegetation condition. Furthermore, total carbon stock from stand biomass measurement is also an important parameter used to assess forest condition. Stand biomass is usually calculated using linear regression equation and non-linear based on species observation, as obtained from the field measurement (Crow and Schlaegel 1988; Hahn 1984; Ohmann and Grigal 1985), as well as a process-based model, namely 3-PG (physiological principles for predicting growth). Although the estimation of above-ground biomass (AGB) varies according to some parameters such as species composition and structure, basal area and height, estimating the AGB using diameter at breast height (DBH) is the most general method (Crow and Schlaegel 1988). Several models of regression equations have been developed for estimating the AGB (Hahn 1984; Ohmann and Grigal 1985) since this model is precise when applied at tree, plot and stand level. However, it cannot be used to analyze the spatial pattern of AGB with respect to the whole landscape. To estimate AGB at landscape level, various vegetation indices from remote sensing data can be applied (Perala and Alban 1994). Budiharta et al. (2014) applied a process-based model by using soil and climate data, and vegetation indices, namely 3-PG (physiological principles for predicting growth) in estimating the AGB of Bornean primary forest.

Furthermore, this study was focused on agroforestry practices which is considered a land-use system that delivers multiple benefits not only from social aspect but also from biophysical perspective and other ecosystem functions. According to Budiharta et al. (2016), social and ecological aspects have strong and important impact for restoration program in Indonesia. Agroforestry practices can be classified into simple agroforestry and complex agroforestry. Simple agroforestry is defined as agroforestry that consists of at least two types of plant which are trees and at least one species of agricultural or horticultural plant. Complex agroforestry, on the other hand, is a combination of agricultural systems which involve various trees species, characterized by trees with multilayers and an ecosystem that is similar to primary or secondary forests. Agroforestry practices in this research are classified into 'complex agroforestry' or 'agroforests'.

The objectives of the research were to investigate the correlation between: (i) the value of FCD (\%) and tree stand density (N/ha); (ii) the value of FCD (\%) and basal area $\left(\mathrm{m}^{2} / \mathrm{ha}\right)$; (iii) the value of FCD $(\%)$ and total carbon stock (Mg C/ha); and (iv) total carbon stock and percentage of canopy closure (\%) as measured by local community using conventional measurement method.

\section{MATERIALS AND METHODS}

\section{Study area and period}

The study area of this research was conducted in Birang Village and Merabu Village, Berau District, East Kalimantan, Indonesia (Figure 1). Berau's area 75\% covered by forest and reported in high biodiversity status. Berau is one of a pilot project to demonstrate REDD+ in Indonesia. REDD+ program was in line with this research, related to carbon stock measurement specifically. This research was started in January 2016 until January 2017.

\section{Data collection}

The data utilized in this research were categorized into two types: primary and secondary data. Primary data included all of the data that were collected in the field. Secondary data included all information that was obtained from other sources, e.g. maps and general conditions of study sites. The general overview of data used in this study is presented in Table 1. 

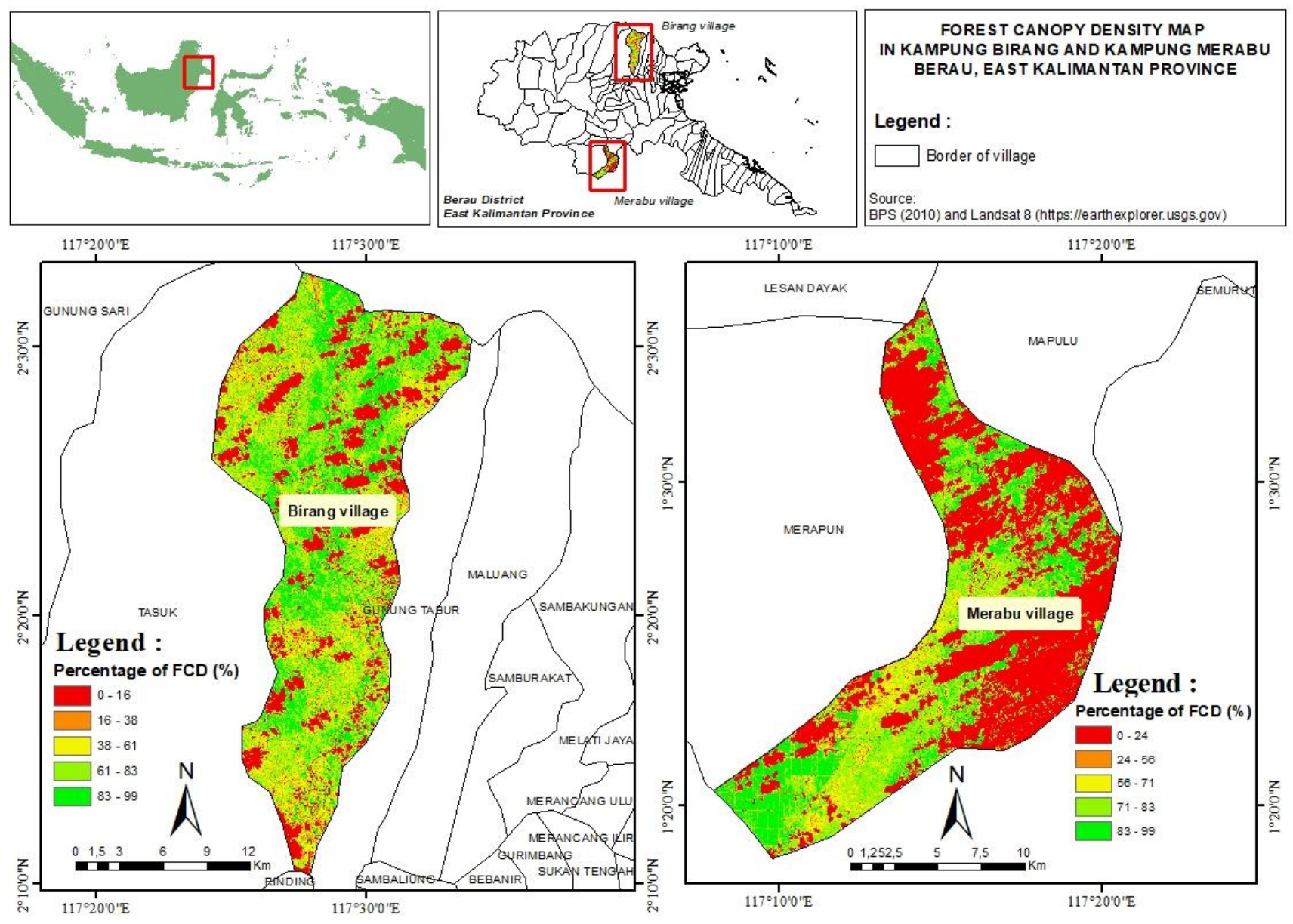

Figure 1. The location of research sites in Birang Village and Merabu Village, Berau, East Kalimantan, Indonesia

Table 1. Types of data used in this research

\begin{tabular}{lll}
\hline Type of data & Data resources & Technique of data collection \\
\hline Landsat Satellite Image 8 in 2014 of & USGS (U.S. Geological & Downloaded from: erthexplorer.usgs.gov \\
Birang Village and Merabu Village & Survey) & \\
Forest canopy density value & Forest canopy density mapper & Forest canopy density software processing (Figure 2) \\
Forest stand density & Field observation & Direct observation by local community \\
Basal area & Field observation & Direct observation by local community \\
Canopy closure & Field observation & Direct observation by local community \\
\hline
\end{tabular}

\section{Forest canopy density mapper \\ Pre-image processing}

Pre-image processing was the first step necessary to process the satellite image. Taken into consideration here were aspects related to process image data importing, layer stacking, rescaling, image subsetting, data importing, selection of band combinations, geometric correction and image subsetting (Rikimaru and Miyatake 2002).

\section{Data processing}

The obtained images were further processed by the FCD mapper v.2.0 software in order to obtain the mapping of the forest canopy density. The procedure for completing the FCD mapping model is shown in Figure 2. The maps of the forest canopy density in Birang Village and Merabu Village can be seen in Figure 3.

According to Rikimaru and Miyatake (2002), forest vegetation condition is assessed based on canopy density. Using this approach, FCD was the calculation of four indices, namely the Advanced Vegetation Index (AVI), Bare Soil Index (BI), Shadow Index (SI) and Thermal Index (TI). The calculations for this study were made after applying 'noise reduction' techniques, specifically related to clouds, cloud shadow and water area as these factors can influence the analysis of imagery data. In case of the presence of cloud shadow, it can be confused with shadow cast because of adjacent mountains. It can be corrected by creating a cloud shadow mask. 


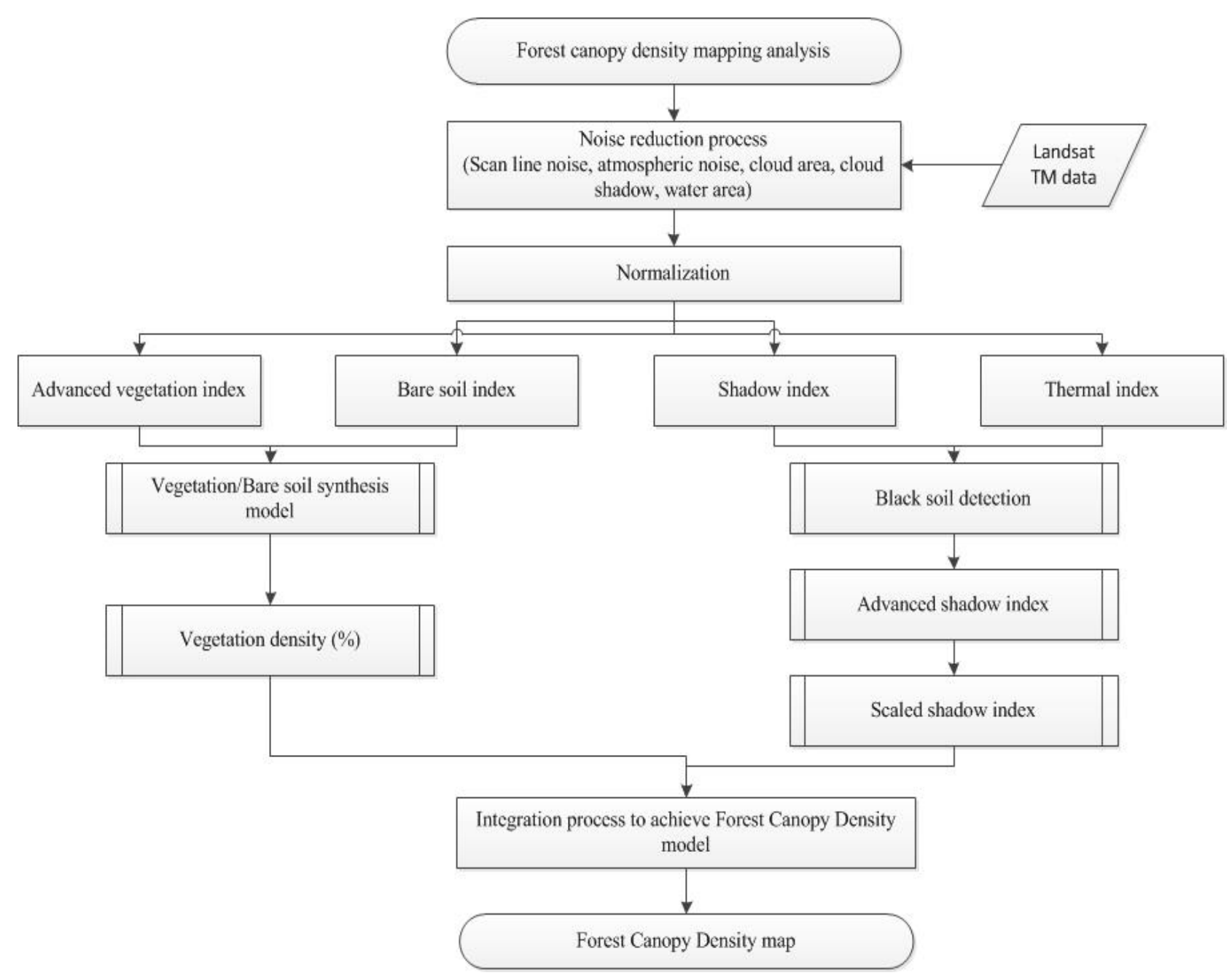

Figure 2. The analytical framework of the FCD mapping model used in this study

\section{Advanced vegetation index (AVI)}

The Vegetation Index is a method to assess the vegetation condition of the forest. The aim of this method is to examine characteristics of chlorophyll-a in which this index is often referred to as the Advanced Vegetation Index (AVI). Advanced vegetation index was formulated as equation 1:

If $\mathrm{B} 43<0$ then $\mathrm{AVI}=0$

If $\mathrm{B} 43>0$ then $\mathrm{AVI}=((\mathrm{B} 4+1) \times(256-\mathrm{B} 3) \times \mathrm{B} 43)^{1 / 3}$

Where:

AVI = advanced vegetation index

B1-B7 = TM Band 1-7 data

$\mathrm{B} 43$ = B4-B3 after normalization of the data range

\section{Bare Soil Index (BI)}

The Bare Soil Index (BI) is a more reliable estimation and is formulated with medium infrared information. Bare soil index was formulated as equation 2 :
$\mathrm{BI}=[(\mathrm{B} 5+\mathrm{B} 3)-(\mathrm{B} 4+\mathrm{B} 1)] /[(\mathrm{B} 5+\mathrm{B} 3)+(\mathrm{B} 4+\mathrm{B} 1)] \times 100$
$+100 ; 0<\mathrm{BI}<200$

Where:

$\mathrm{BI}=$ bare soil index

$\mathrm{B} 3=$ band 3 of Landsat $5 \mathrm{TM} /$ Landsat $7 \mathrm{ETM}$ or band 4 for Landsat 8 OLI

B4 = band 4 of Landsat 5TM/Landsat 7ETM or band 5 for Landsat $8 \mathrm{OLI}$

B5 = band 5 of Landsat 5TM/Landsat 7ETM or band 6 for Landsat 8 OLI Shadow Index (SI)

The Shadow Index (SI) is used to extract information regarding the forest structure and to test the shadow's characteristics by using spectral information on the forest shadow and thermal information on the forest. The shadow index is obtained by the extraction of the low radiance of visible bands. The bare soil index was calculated as follows: 

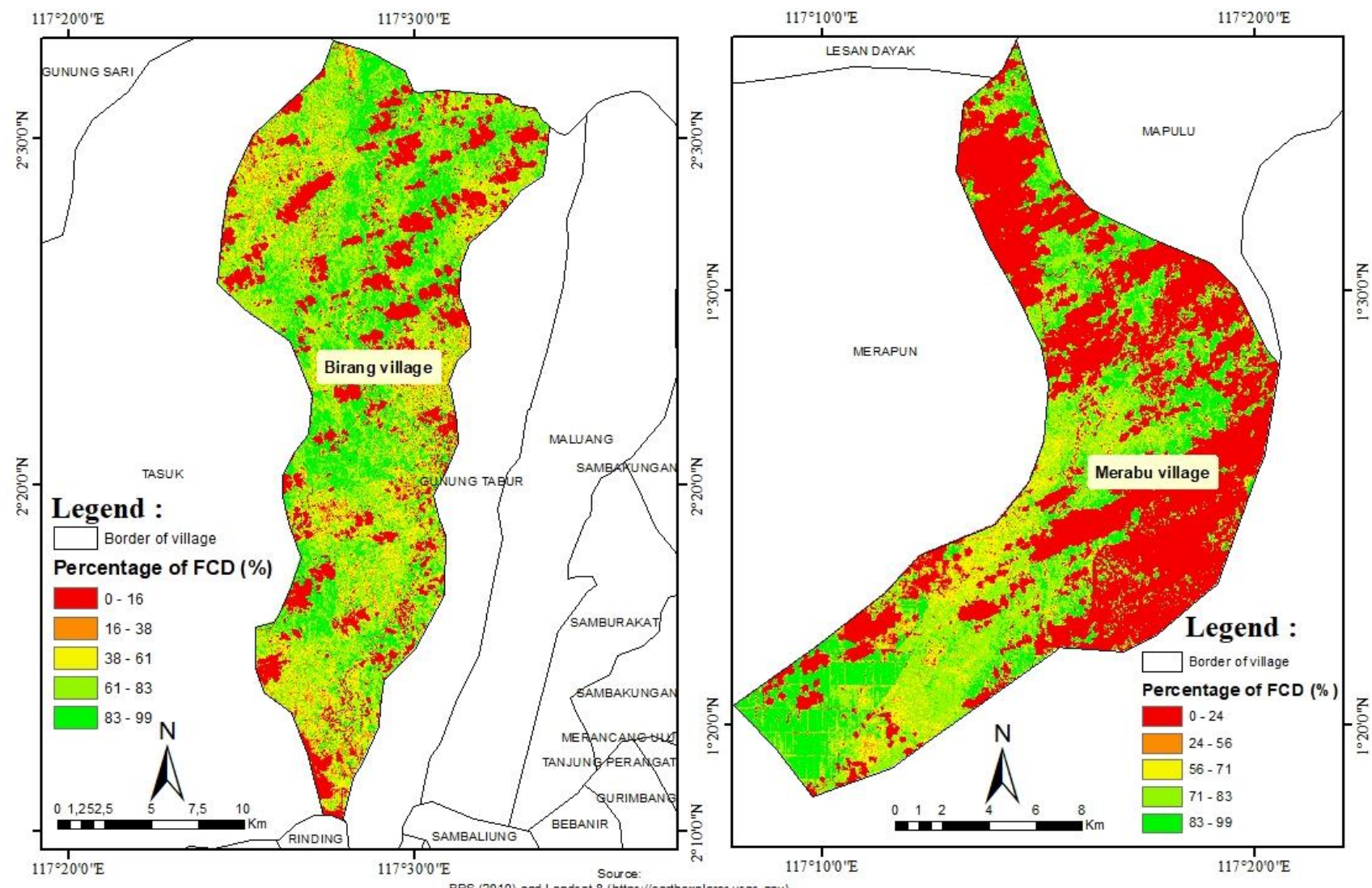

Figure 3. The map of forest canopy density in Birang Village and Merabu, Berau, East Kalimantan, Indonesia

$$
\mathrm{SI}=[(256-\mathrm{B} 1) \times(256-\mathrm{B} 2) \times(256-\mathrm{B} 3)]^{1 / 3}
$$

Where:

$\mathrm{SI}=$ shadow index

$\mathrm{B} 1=$ band 1 of Landsat $5 \mathrm{TM} /$ Landsat 7ETM or band 2 for Landsat 8 OLI

B2 = band 2 of Landsat 5TM/Landsat 7ETM or band 3 for Landsat 8 OLI

B3 = band 3 of Landsat 5TM/Landsat 7ETM or band 4 for Landsat 8 OLI

\section{Thermal Index (TI)}

The low temperature in a forest is affected by two factors. The first is the effect of the height of canopy closure which blocks the sunlight. And the second is the evapotranspiration of leaf and ground surface which result in low temperature. TI is obtained from calibrated value of thermal band information.

The first step is converting Digital Number (DN) of Band 6 (Landsat TM/ETM, or Band 10/Band 11 of Landsat $8 \mathrm{OLI})$ to radiance. After that, the radiance is converted to Brightness temperature. The formula used was calculated as follows:

\footnotetext{
$\mathrm{L}_{\lambda}=\left(\left(\mathrm{LMAX}_{\lambda}-\mathrm{LMIN}_{\lambda}\right) /(\mathrm{QCALMAX}-\mathrm{QCALMIN})\right)^{*}$ $(\mathrm{QCAL}-\mathrm{QCALMIN})+\mathrm{LMIN}_{\lambda}$

Where:

$\mathrm{L}_{\lambda}=$ the cell value as radiance

$\mathrm{QCAL}=$ digital numberof thermal band

$\operatorname{LMIN}_{\lambda}=$ spectral radiance scales to QCALMIN

$\operatorname{LMAX}_{\lambda}=$ spectral radiance scales to QCALMAX

QCALMIN = the minimum quantized calibrated pixel value (typically $=1$ )

QCALMAX = the maximum quantized calibrated pixel value (typically $=255$ )

$\mathrm{BT}=\mathrm{K} 2 / \ln \left[\left(\mathrm{K} 1 / \mathrm{L}_{\lambda}\right)+1\right]$

Where:

BT = brightness Temperature (Kelvin)

$\mathrm{L}_{\lambda}=$ the cell value as radiance (Watts $\left./\left(\mathrm{m}^{2 *} \operatorname{srad}^{*} \mu \mathrm{m}\right)\right)$

$\mathrm{K} 1=$ constant $(774.89)$

$\mathrm{K} 2$ = constant (1 321.08)

$\mathrm{C}=\mathrm{T}-273$

Where:

$\mathrm{C}=$ temperature $\left({ }^{\circ} \mathrm{C}\right)$

$\mathrm{T}=$ temperature $\left({ }^{\circ} \mathrm{K}\right)$ 


\section{Tree stand density, basal area, and total carbon stock measurement}

The data obtained from the Landsat image was analyzed through ground-truthing. Tree circumference was measured at the breast height to calculate basal area and total carbon stock. The local community identified species according to local name, then the numbers of tree species were used to calculate the tree stand density.

\section{Plot sampling}

Selected plots were defined based on forest canopy density value resulting from the Forest Canopy Density mapper and using the following criteria: (i) area should represent agroforestry system; (ii) owned and tended by the local community; and (iii) accessibility. In total, there were five classes of FCD values. Furthermore, each class consisted of 6 plots (Figure 3), resulting in a total of 60 plots in two villages. The plot size was $50 \mathrm{~m} \times 50 \mathrm{~m}$, in accordance with Huang et al. (2006) who utilized plots of $50 \mathrm{~m} \times 50 \mathrm{~m}$ with a resolution image between 20-30 meters. In our research, measurements were conducted for 2 levels of vegetation: trees with a 'medium diameter' $(10 \mathrm{~cm} \leq \mathrm{D}<$ $20 \mathrm{~cm})$ and trees with a 'large diameter' $(\mathrm{D} \geq 20 \mathrm{~cm})$.

\section{Training the local community and species identification}

Training for members of the local community was conducted to establish the plots, measure the tree diameter and do tree tagging, as well as to measure the canopy profile. The trained local communities were typically the owners of the agroforest or the members of the local community who showed their willingness and interest to be involved in the carbon assessment program. All of the species in the plots were identified by botanists and community members. Furthermore, the community identified the species according to local names, whereas botanists identified species according to scientific names.

\section{Tree density, basal area and total carbon stock}

After receiving training, the community members calculated the number of medium and large diameters trees. The number of medium and large diameter trees were then used to calculate the density (N/ha). Additionally, the circumferences of both medium and large trees were measured at breast height $(130 \mathrm{~cm})$ and were then converted into a diameter-based value. The diameter value was further used to calculate the basal area $\left(\mathrm{m}^{2} / \mathrm{ha}\right)$ and the total carbon stock $(\mathrm{Mg} \mathrm{C} / \mathrm{ha})$. In addition to tree diameter value, the wood density $\left(\mathrm{g} / \mathrm{cm}^{3}\right)$ of each species was used to calculate the carbon stock.

\section{Canopy profile measurement}

The canopy profile measurement was conducted by drawing a diagram of the canopy profile with a length and width of $50 \times 50 \mathrm{~m}$ and measuring the canopy projection area on the ground. The necessary data for the canopy stratification included: Tree position in a row which was sequentially measured from the same direction and distance from the starting point of tree measurement. Thus, trees were observed in (i) Pre-defined lines. (ii) Total height and height of free branch trees. (iii) Projection of canopy on the ground (length and width of the canopy of each tree).

The canopy profile was measured in 3 of the plots in each village, with a total of 6 plots being measured. Furthermore, these plots had to represent high, medium, and low tree density. Data were then obtained by measuring the canopy projection area on the ground.

The canopy stratification is classified based on the classification of canopy height according to Soerianegara (1996) as follows: (i) Stratum A consisting of trees with a height of $>30 \mathrm{~m}$. (ii) Stratum B consisting of trees with a height of 20-30 m. (iii) Stratum C consisting of the trees with a height of 4-20 m. (iv) Stratum D consisting of the vegetations with a height of $1-4 \mathrm{~m}$. (v) Stratum E consisting of the vegetations with a height of $<1 \mathrm{~m}$.

\section{Canopy closure calculation}

The canopy closure was calculated based on the canopy profile as seen from above. A scoring was then given to each of the canopy profiles, i.e., a score of $4(100 \%)$ indicates a full closure, score $3(75 \%)$, score $2(50 \%)$, score $1(25 \%)$ and a score of 0 indicates no closure. The scores were then summed in each plot. The example is further elaborated as presented in Figure 4 according to the following equation:

$$
\mathrm{T}_{\mathrm{i}}=\mathrm{T}_{1}+\mathrm{T}_{2}+\ldots . .+\mathrm{T}_{100}
$$

Where:

$\mathrm{Ti}=$ canopy closure

$\mathrm{Tn}=$ scoring in each plot

\section{Data analysis}

The assumption of the classic test

A regression model can be identified as being a good model when it is free from the problems of normality, heteroscedasticity, and autocorrelation (Rosadi 2011). For this research, only the normality and the heteroscedasticity tests were employed due to the lack of a time series observation required for the autocorrelation test.

The normality test was performed at the $5 \%$ significance level using the Kolmogorov Smirnov test (K-S). The data was found to have a normal distribution if $p$-value $\geq 0.05$. The data can be obtained via the K-S statistic test using the Minitab 15 software.

One of the requirements for a regression analysis to be applied is that the data should not exhibit heteroscedasticity, i.e., the data must be homoscedastic. Heteroscedasticity occurs when there is a dissimilarity of residual variance between a variable of interest (FCD) and other variables (tree stand density, basal area and total carbon stock). Heteroscedasticity can be tested via a scatterplot test, or Glejser test, using the Minitab 15 software. When the scatterplot appears as randomly distributed without any patterns, it is an indication that there is no heteroscedasticity present. The Glejser test hypothesis is as follows:

If $\mathrm{P}$-value $<0.05$ indicates heteroscedasticity If $\mathrm{P}$-value $>0.05$ indicates no heteroscedasticity 


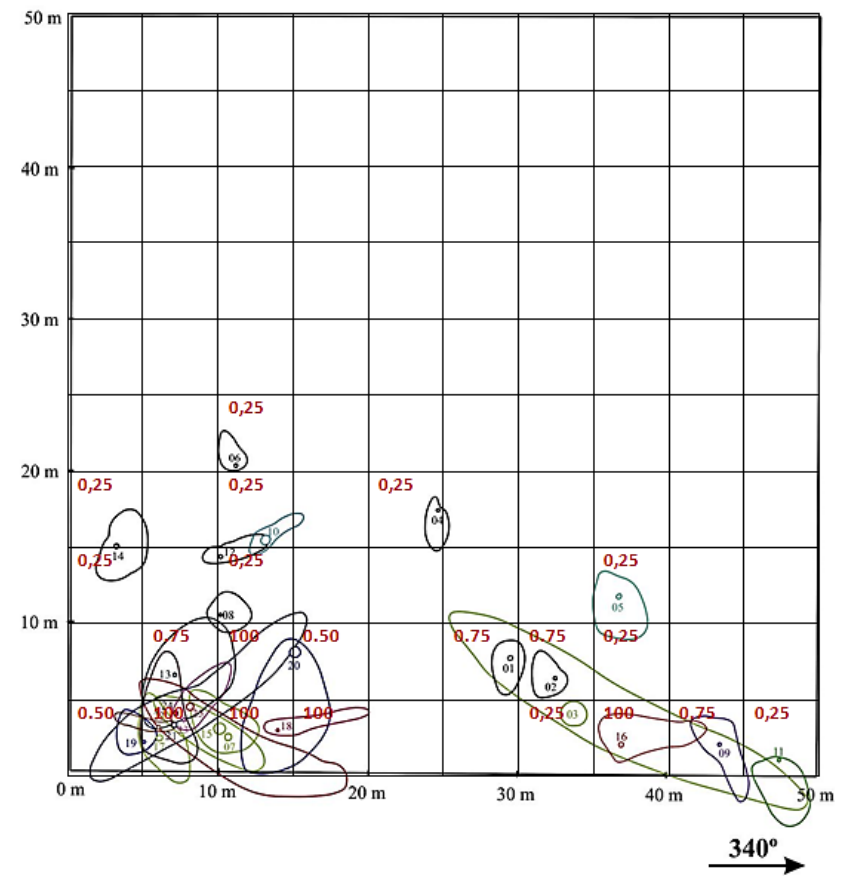

Figure 4. Canopy closure scoring

\section{Linear regression model}

The regression analyzed in this research were between FCD and tree stand density, basal area and total carbon stock. The highest coefficient determination $\left(\mathrm{R}^{2}\right)$ indicated that the model was a good fit for the data after meeting the necessary classic assumptions. Further, a simple linear regression is applied as follows (Walpole 1992):

$$
\mathrm{Y}=a+b x
$$

Where:

$\mathrm{Y}=$ dependent variable (stand density, basal area, and total carbon stock)

$a, b=$ regression coefficient

$x=$ independent variable (FCD value)

\section{Validation of linear regression model}

Validation of the model is intended to determine the deviation of the data. Approximately $30 \%$ of the data were used for validation, while the remaining $70 \%$ were used for the development of the regression model (Wibowo et al. 2010). The accuracy value was calculated as follows:

$$
\text { Accuracy }=\frac{\bar{\chi}-\bar{\mu}}{\bar{\mu}}
$$

Where:

$\bar{\chi}=$ average of the model estimation value

$\bar{\mu}=$ average of the actual value

\section{RESULTS AND DISCUSSION}

Forest Canopy Density (FCD) is one of the most important parameters to measure the planning and implementation of afforestation, reforestation and rehabilitation of logged-over areas. The FCD method is also useful for the MRV (Monitoring, Reporting, and Verification) implementation of the REDD+ scheme.

\section{The relationships between forest canopy density, tree stand density, basal area and total carbon stock in agroforestry practices}

In this study, a total of 60 plots was established as ground-truthing sites to develop a prediction model of tree stand density using FCD. Based on the FCD analysis, there were 12 unaccounted plots ( 0 value) as there were cloud, cloud shadow and edge of the water which made the plots unusable. Based on the Minitab 15 analysis, there were 2 outlier plots. Thus, a total of 46 plots consisting of 32 plots used for model development and 12 plots for model validation.

The relationships between FCD and tree stand density analysis was intended to indirectly estimate tree stand density in the field by developing a regression model between FCD as a predictor and tree density as a response. The regression model between FCD and tree density as shown in equation 10 had results of $\mathrm{R}^{2}=37.7 \%$ (Figure 5) and $r=61.4 \%$ (Table 2). The tree stand density maps in Birang Village and Merabu Village are shown in Figure 6.

Tree stand density $(\mathrm{N} / \mathrm{ha})=26.6+3.72 \mathrm{FCD}$

The regression model between the FCD and basal area is shown in equation 11 with $\mathrm{R}^{2}=3.33 \%$ (Figure 7) and $\mathrm{r}=$ $18.3 \%$ (Table 3 ). The basal area maps from Birang Village and Merabu Village are shown in Figure 8. Figure 9 shows the regression between tree stand density and total carbon stock in agroforestry practices.

$$
\text { Basal area }\left(\mathrm{m}^{2} / \mathrm{ha}\right)=10.2+0.0735 \mathrm{FCD}
$$

\section{Model performance}

The results of our study suggest that FCD model is better in estimating tree stand density than basal area (Table 2). The result of the classical assumption test showed that both models are normally distributed (Figure 10). There was no heteroscedasticity in the tree stand density model, however, there was heteroscedasticity in the basal area model (Table 3). The validation test showed that the model estimation of tree stand density using FCD had higher reliability with $7.85 \%$ of error than basal area with $14.63 \%$ of error (Table 4 ).

The result of normality test showed that the total carbon stock predicted by FCD models were distributed normally (Figure 10). The total carbon stock model as estimated by the FCD in Birang Village and Merabu Village is shown in equation 16. Carbon stock map in Birang Village and Merabu Village are showed in Figure 11. 
Total carbon stock $(\mathrm{Mg} \mathrm{C} / \mathrm{ha})=7.1+0.222$ tree stand density

Tree stand density $(\mathrm{N} / \mathrm{ha})=26.6+3.72 \mathrm{FCD}$

Total carbon stock $(\mathrm{Mg} \mathrm{C} / \mathrm{ha})=7.1+(0.222(26.6+3.72 \mathrm{FCD}))$

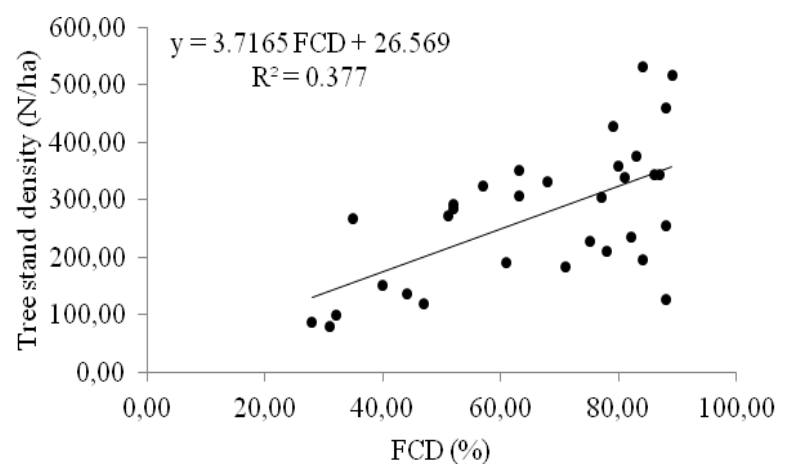

Figure 5. The relationship between FCD and tree stand density in agroforest at the study sites

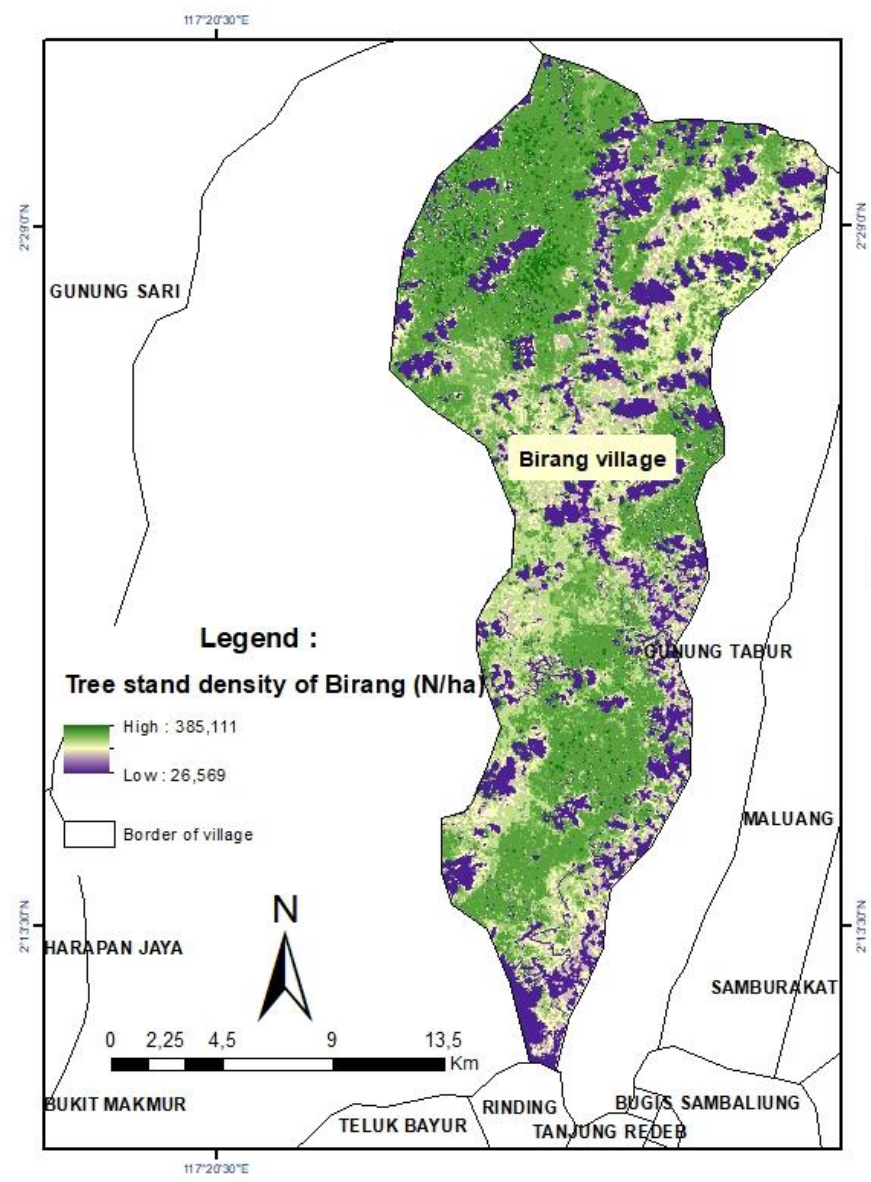

Figure 6. Tree stand density map in Birang Village and Merabu Village, Berau, East Kalimantan, Indonesia 

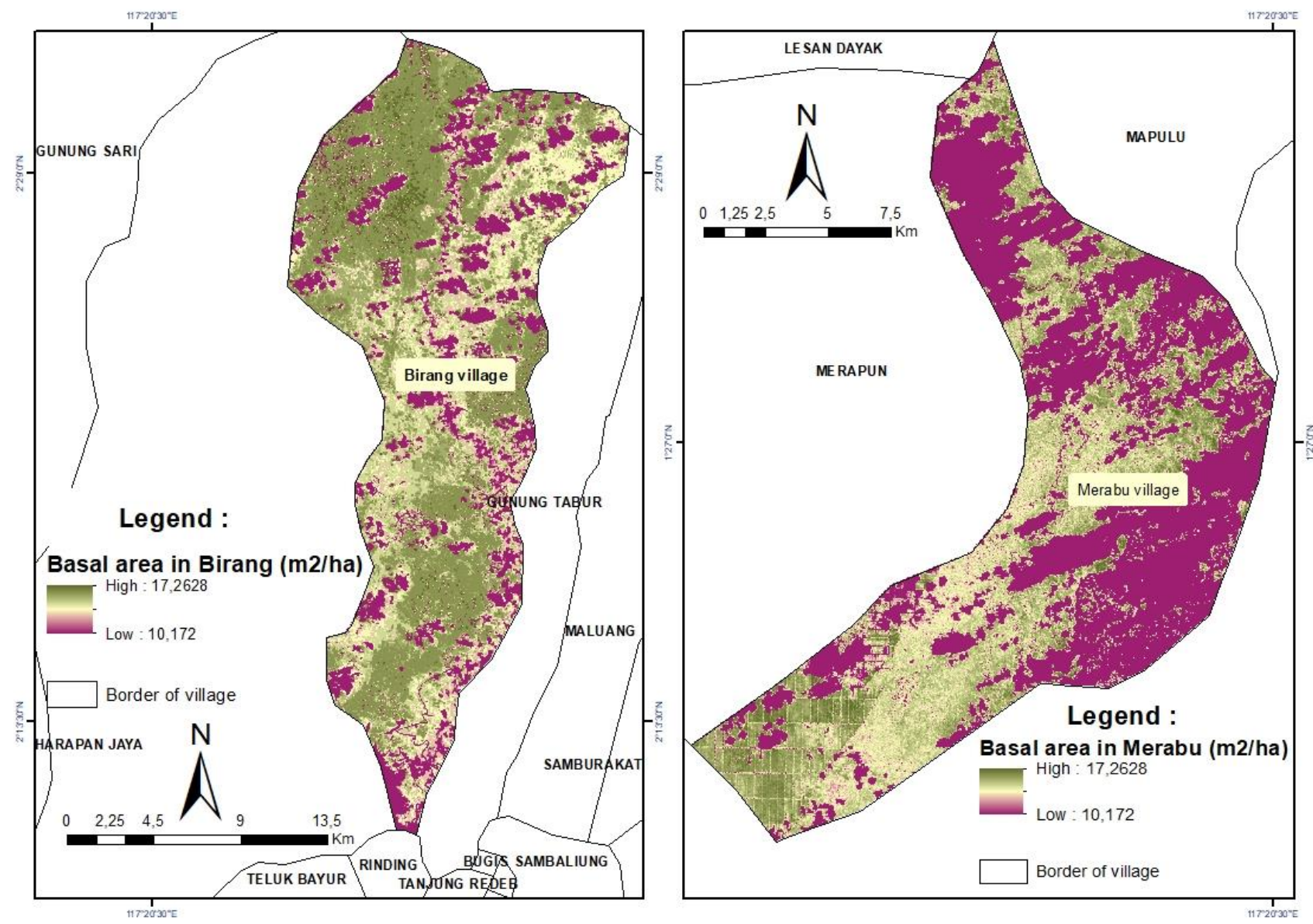

Figure 8. Basal area map in Birang Village and Merabu Village, Berau, East Kalimantan, Indonesia

Table 2. The prediction model for tree stand density, basal area and total carbon stock

\begin{tabular}{lllll}
\hline Dependent variables $(\mathbf{Y})$ & Independent variable $(\mathbf{X})$ & Model & r $(\boldsymbol{\%})$ & $\mathbf{R 2}(\boldsymbol{\%})$ \\
\hline Tree stand density & Forest canopy density & Tree stand density $(\mathrm{N} / \mathrm{ha})=26.6+3.72 \mathrm{FCD}$ & 61.4 & 37.7 \\
Basal area & Forest canopy density & Basal area $\left(\mathrm{m}^{2} / \mathrm{ha}\right)=10.2+0.0735 \mathrm{FCD}$ & 18.3 & 3.3 \\
Total carbon stock & Tree stand density & Total carbon $(\mathrm{Mg} \mathrm{C} / \mathrm{ha})=7.1+0.222$ tree density & 27.3 & 27.7 \\
\hline
\end{tabular}

Table 3. The result of normality and heteroscedasticity test

\begin{tabular}{|c|c|c|}
\hline Model & Normality test (K-S) & Heteroscedasticity \\
\hline Tree stand density $(\mathrm{N} / \mathrm{ha})=26.6+3.72 \mathrm{FCD}$ & p-val >0.150 (normal) & 0.113 (no heteroscedasticity) $^{\mathrm{a})}$ \\
\hline Basal area $\left(\mathrm{m}^{2} / \mathrm{ha}\right)=10.2+0.0735 \mathrm{FCD}$ & p-val $>0.150$ (normal) & 0.047 (heteroscedasticity) $^{\mathrm{a})}$ \\
\hline Total carbon stock $(\mathrm{Mg} \mathrm{C} / \mathrm{ha})=7.1+0.222$ tree density & $\mathrm{p}-\mathrm{val}=0.121$ & no heteroscedasticity ${ }^{\mathrm{b})}$ \\
\hline
\end{tabular}

Note: a) Glejser test; b) scatterplot test

Table 4. The validation test of the prediction model for tree stand density, basal area and carbon stock

\begin{tabular}{llll}
\hline Dependent variables $(\mathbf{Y})$ & Independent variable $(\mathbf{X})$ & Model & Reliability $(\%)$ \\
\hline Tree stand density & Forest canopy density & Tree stand density $(\mathrm{N} / \mathrm{ha})=26.6+3.72 \mathrm{FCD}$ & 7.85 \\
Basal area & Forest canopy density & Basal area $\left(\mathrm{m}^{2} / \mathrm{ha}\right)=10.2+0.0735 \mathrm{FCD}$ & 14.63 \\
Total carbon stock & Tree stand density & Total carbon stock $(\mathrm{Mg} \mathrm{C} / \mathrm{ha})=7.1+0.222$ tree density & 25.8 \\
\hline
\end{tabular}




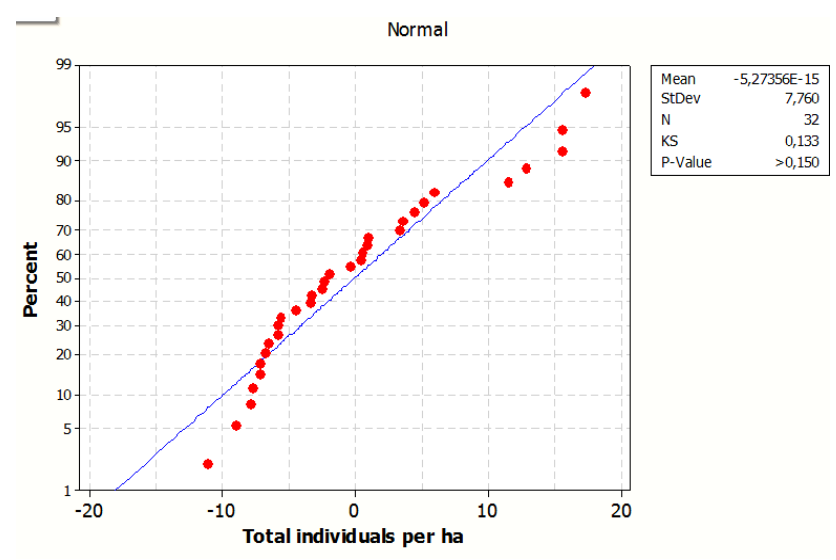

A

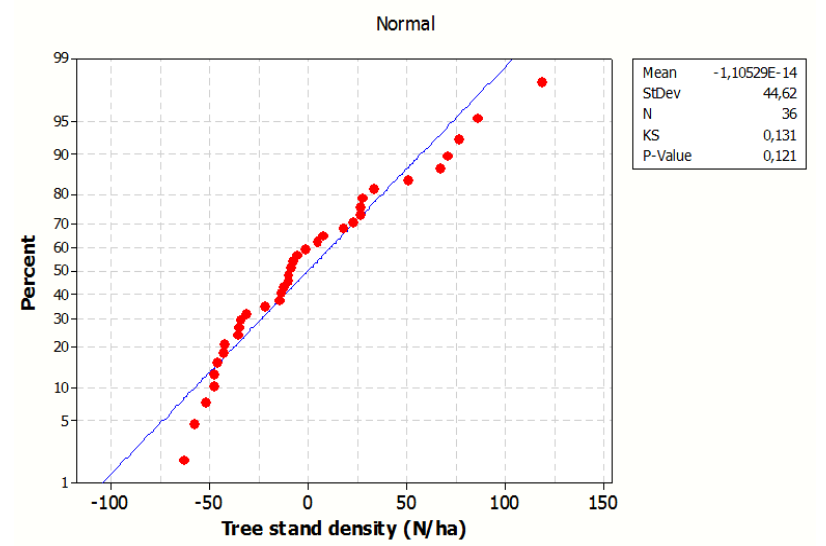

C
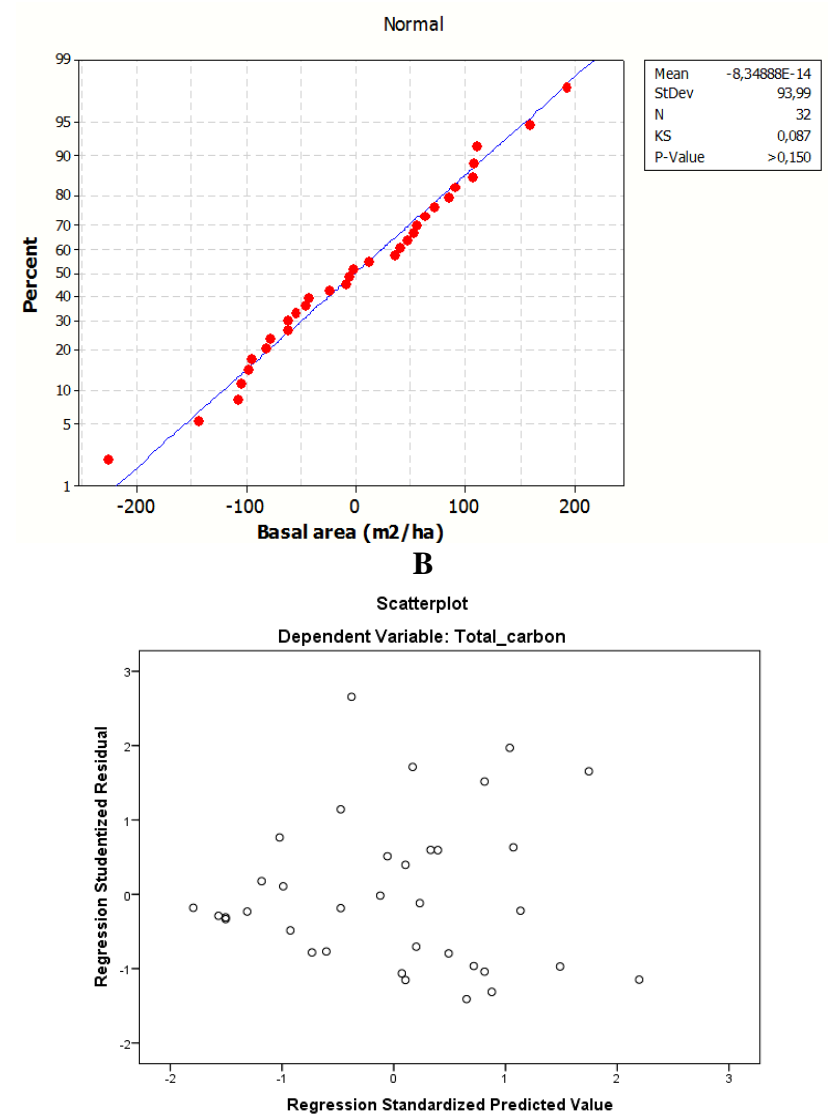

D

Figure 10. The normality test for total individuals per ha (A), basal area (B), tree stand density (C), and scatterplot distribution as a heteroscedasticity test (D)

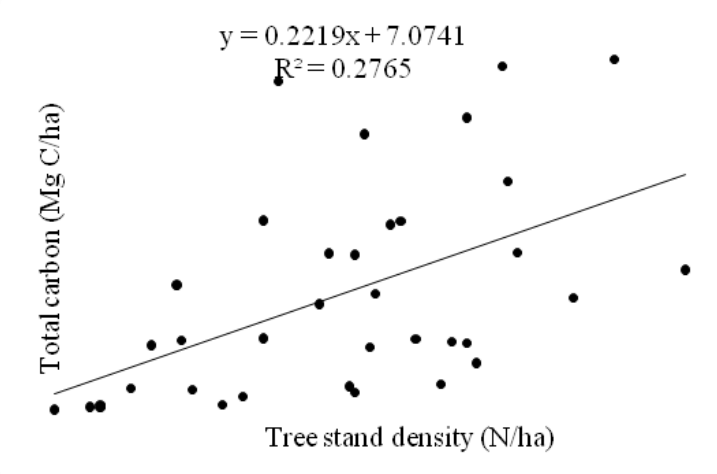

Figure 9. The relationship between tree stand density and total carbon stock in agroforest at the study sites

\section{The relationship between tree architecture profile and carbon stock}

Six plots were used to measure canopy profile. Based on the FCD analysis, there was one plot removed due to cloud shadow, resulting in five plots being analyzed the relationship between FCD and tree density (Figure 12.A).
However, the six plots were used to analyze the relationship between carbon and canopy closure (Figure 12.B).

The total number of tree individuals in plot 2.6 in Birang Village was the lowest among all plots (Table 5). In this plot, the tree stands dominated at the $\mathrm{C}$ stratum with height between 4 and $20 \mathrm{~m}$ and was located at $10 \mathrm{~m}$ from the central point of the established plot. The stand density was rarely dense when it was seen horizontally and vertically (Figure 13a). According to the Department of Forestry (1992), there are three density classes: 1) Dense, if the canopy covers $>70 \%$, 2) Moderately dense, if the canopy covers $40-70 \%, 3$ ) Rarely dense, if there the canopy covers $<40 \%$. In plot 2.6 in Birang Village, the FCD value was $32 \%$ and tree density was $100 \mathrm{~N} / \mathrm{ha}$.

Plot 05 in Merabu Village had the highest number of individuals among all plots. In this plot, the tree stands were distributed across stratum A to D with dominantly were found at stratum $C(4-20 \mathrm{~m})$. The tree stands were located at $10 \mathrm{~m}$ and $50 \mathrm{~m}$ from the central point of the established plot. The tree stand density was highly dense, when it was seen both horizontally and vertically (Figure 14.C). 

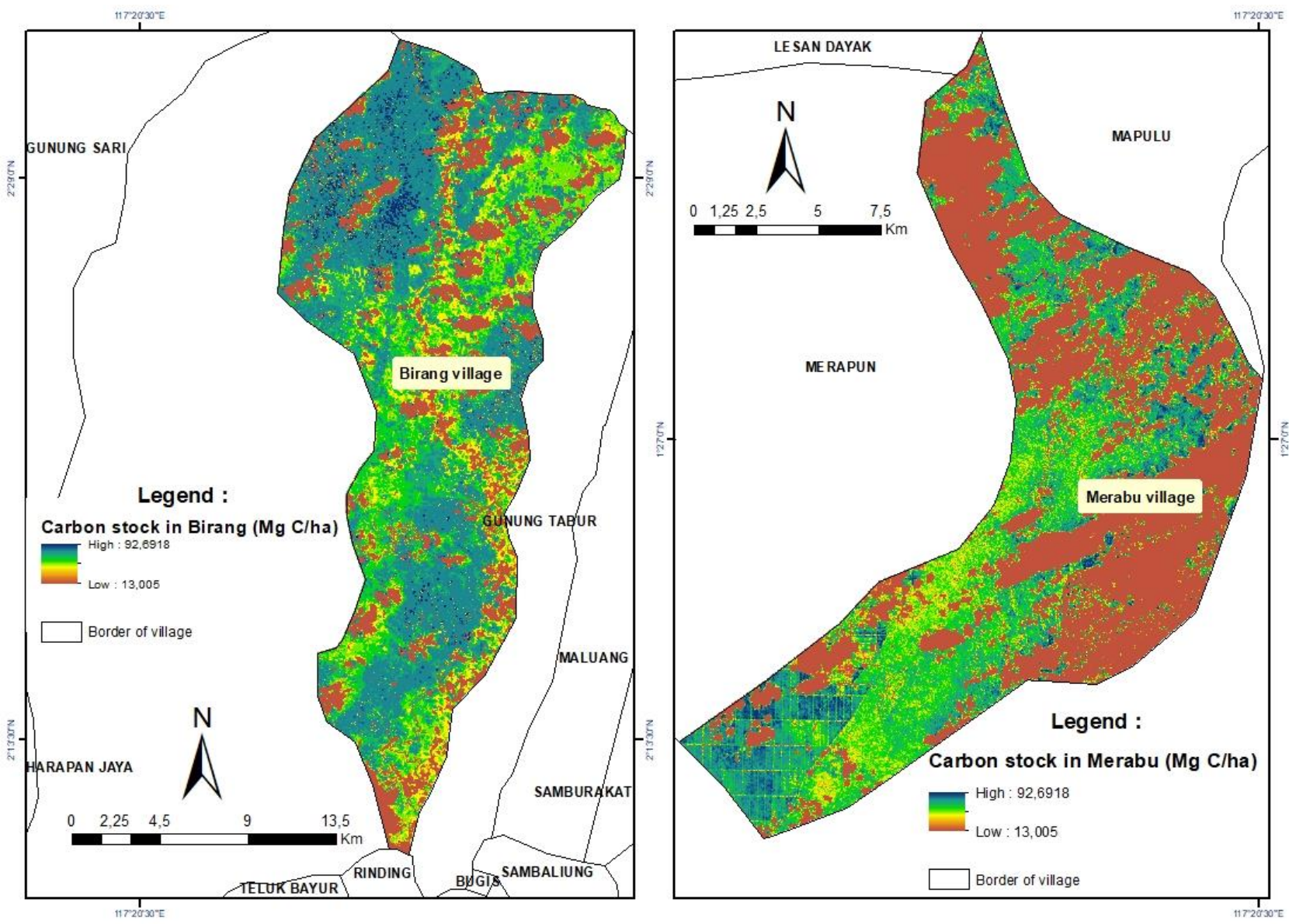

Figure 11. Carbon stock map in Birang Village and Merabu Village, Berau, East Kalimantan, Indonesia

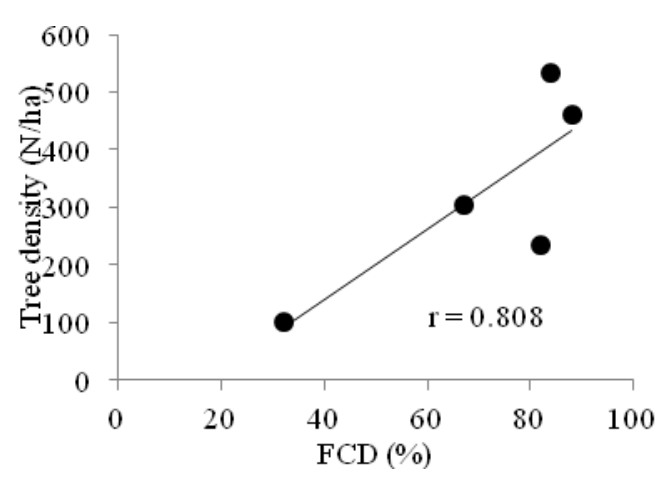

A

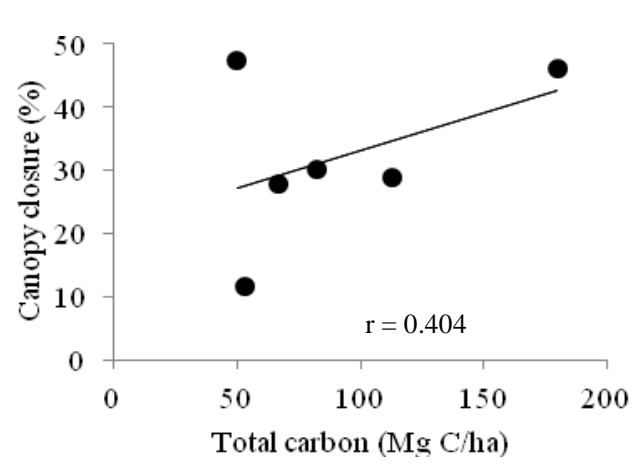

B

Figure 12. The regression model between: A. Tree density (N/plot) and FCD (\%); B. Canopy closure (\%) and carbon (Mg/ha)

Table 5. The summary of canopy profile based on stratification class (Soerianegara 1996) in regard to the number of individuals, FCD, canopy closure and tree density

\begin{tabular}{|c|c|c|c|c|c|c|c|c|}
\hline \multirow[t]{2}{*}{ Locations } & \multicolumn{4}{|c|}{$\begin{array}{c}\text { Number of individuals in } \\
\text { the stratum }\end{array}$} & \multirow{2}{*}{$\begin{array}{r}\text { FCD } \\
(\%)\end{array}$} & \multirow{2}{*}{$\begin{array}{l}\text { Density } \\
\text { (N/ha) }\end{array}$} & \multirow{2}{*}{$\begin{array}{c}\text { Canopy closure } \\
(\%)\end{array}$} & \multirow{2}{*}{$\begin{array}{c}\text { Carbon stock (Mg } \\
\text { C/ha) }\end{array}$} \\
\hline & $\mathbf{A}$ & B & $\mathrm{C}$ & D & & & & \\
\hline Birang Village plot 2.6 & 6 & 2 & 17 & 0 & 32 & 100 & 11.75 & 52.81 \\
\hline Birang Village plot 10 & 0 & 0 & 59 & 2 & 82 & 236 & 30.25 & 82.30 \\
\hline Birang Village plot 30 & 0 & 7 & 111 & 0 & 88 & 460 & 46.25 & 179.59 \\
\hline Merabu Village plot 29 & 2 & 6 & 22 & 0 & 0 & 116 & 27.75 & 66.40 \\
\hline Merabu Village plot 12 & 0 & 2 & 54 & 0 & 67 & 304 & 29.00 & 112.61 \\
\hline Merabu Village plot 05 & 1 & 6 & 132 & 4 & 84 & 532 & 47.50 & 49.86 \\
\hline
\end{tabular}



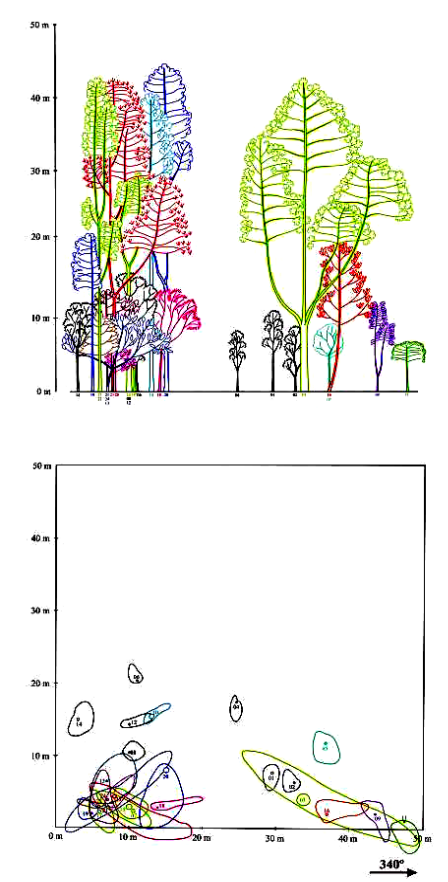

A
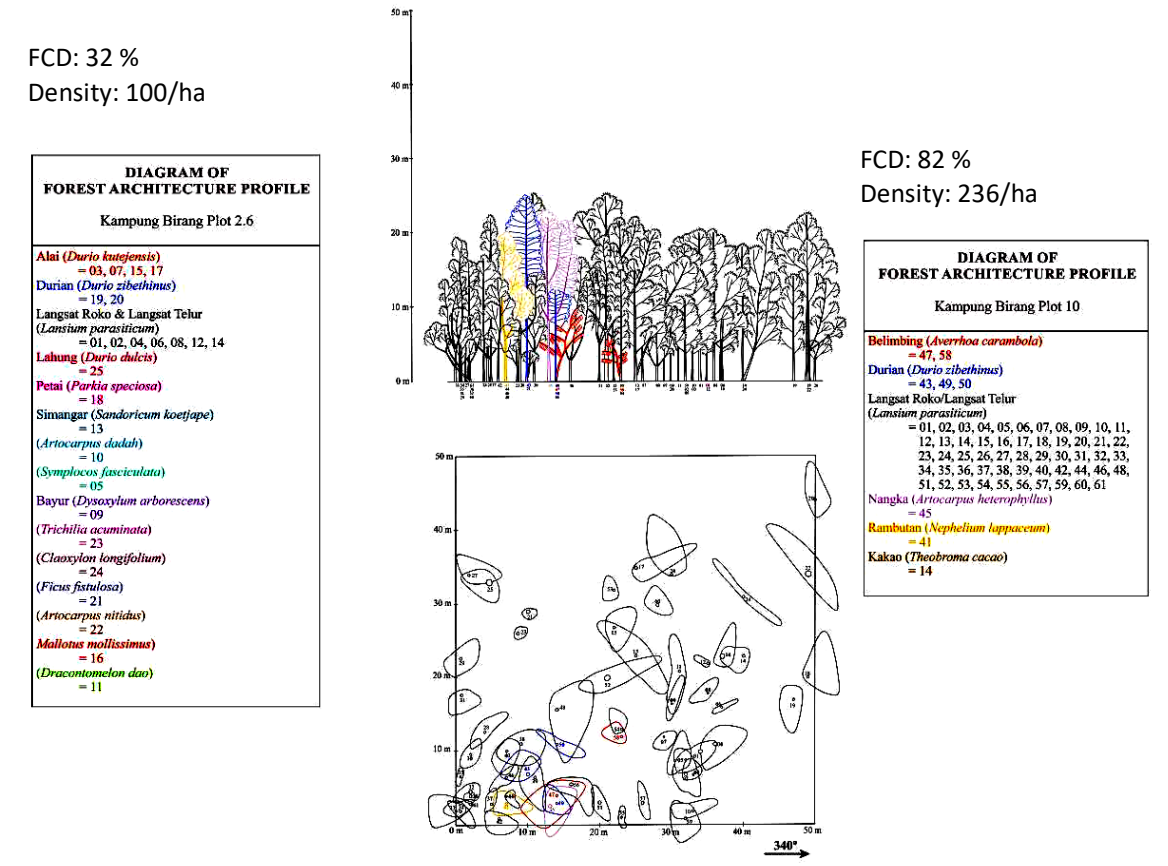

B

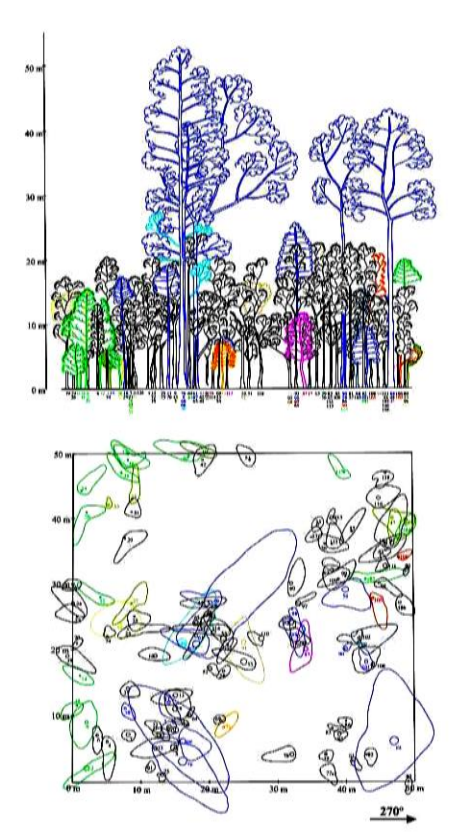

C
FCD: $88 \%$

Density: $460 /$ ha

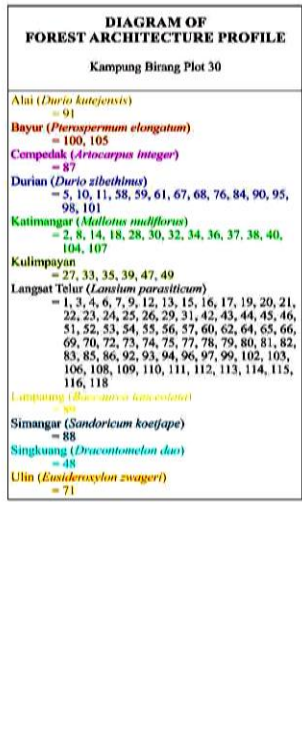

Figure 13. The profile of the forest architecture profile in Birang Village, Berau, East Kalimantan, Indonesia: A. Plot 2.6, B. Plot 10, C. Plot 30 


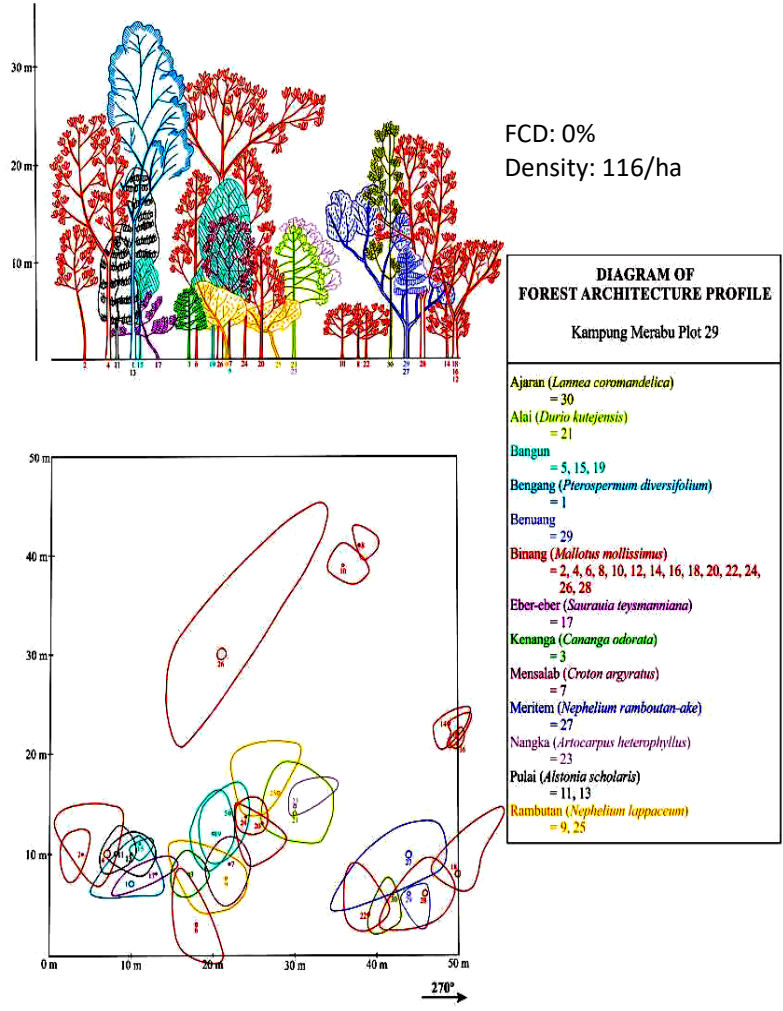

A
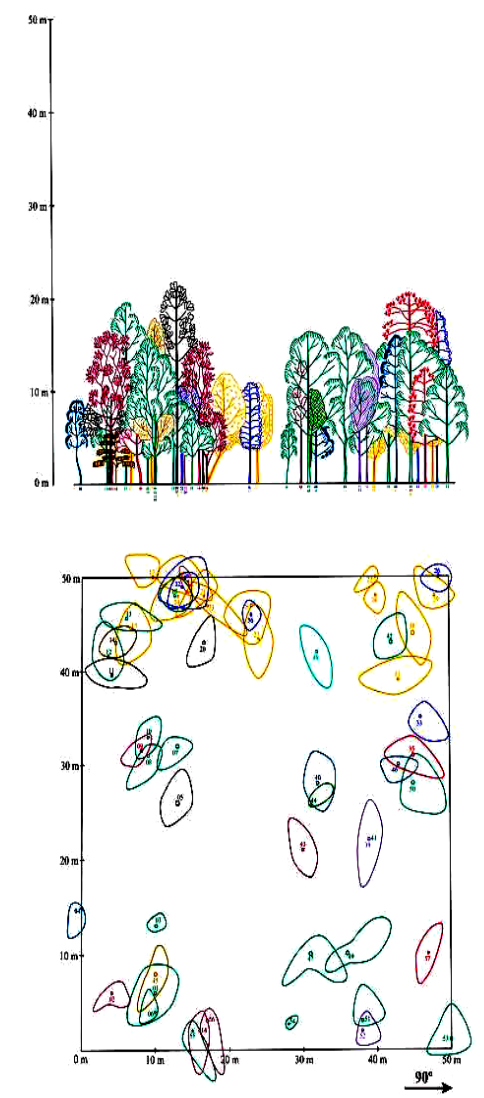

B

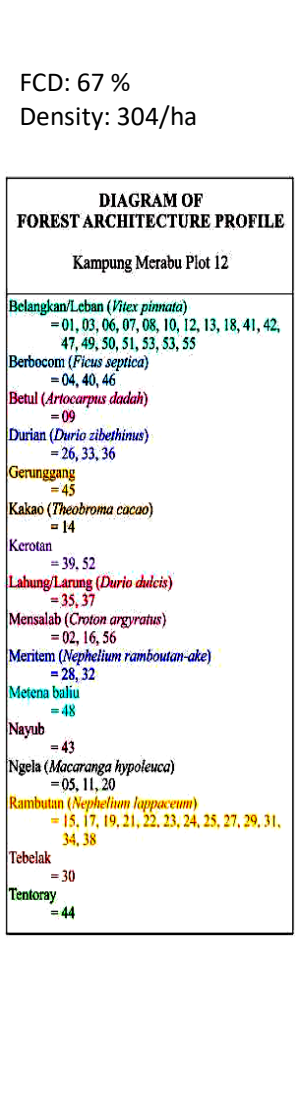

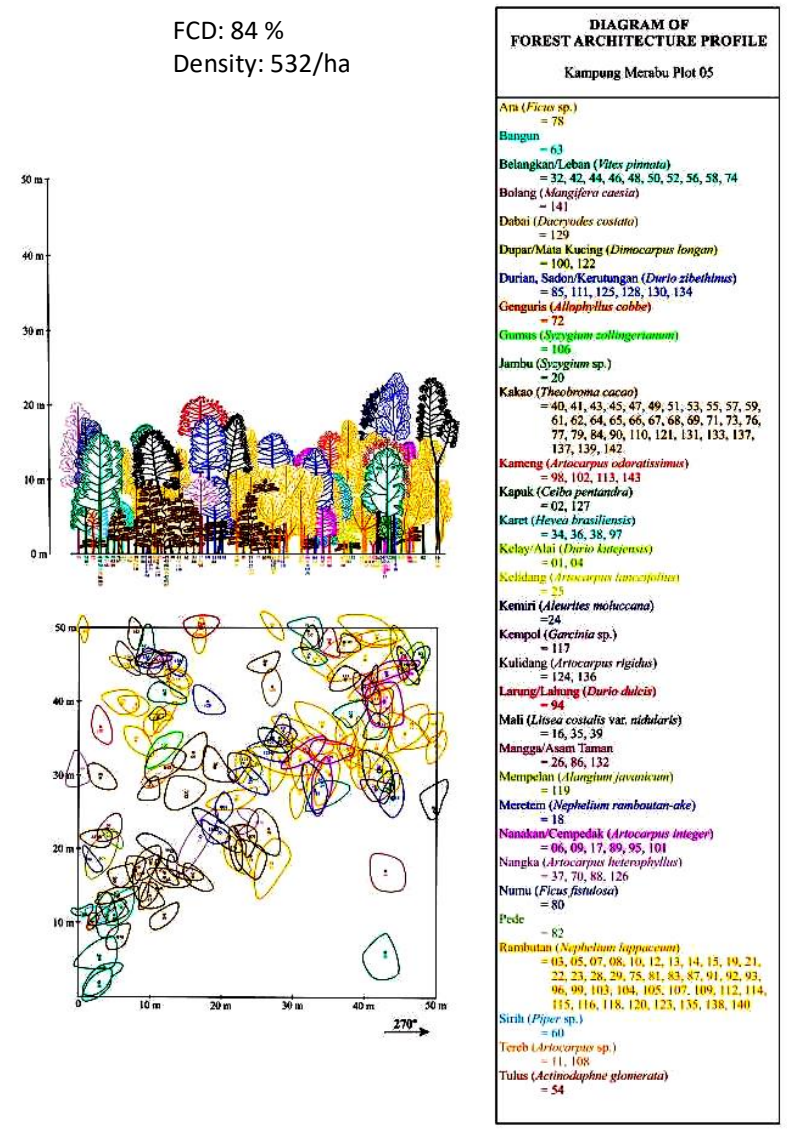

C

Figure 14. The profile of the forest architecture profile in Merabu Village, Berau, East Kalimantan, Indonesia: A. Plot 29, B. Plot 12, C. Plot 05 


\section{Discussion}

FCD mapping uses forest canopy density parameter as an important parameter when characterizing forest vegetation condition. FCD data can be employed to indicate the degrees of forest degradation as well as vegetation condition as a result of rehabilitation (Rikimaru and Miyatake 2002). FCD classifications range between 0$100 \%$ and show the percentage of vegetation canopy density in a stand (Joshi et al. 2006; Khairiah et al. 2016). Our study showed that the classification of FCD in Birang Village and Merabu Village villages ranged between 0$99 \%$, and can be classified into 5 classes which varied among villages. The FCD classes in Birang Village were very low (0-16\%), low (16-38\%), moderate (38-61\%), high $(61-83 \%)$ and very high $(83-99 \%)$. The FCD classes in Merabu Village were very low (0-24\%), low (24-56\%), moderate $(56-71 \%)$, high $(71-83 \%)$ and very high (83$99 \%)$. These classes were obtained from four indices, namely advance vegetation index (AVI), bare soil index (BI), shadow index (SI) and thermal index (TI). These four indices were used to calculate the canopy density for each pixel (in percentage). The advanced vegetation index (AVI) influences the vegetation quantity in comparison to the NDVI. The shadow index (SI) will increase along with the increase in forest density, while the thermal index (TI) will increase when the vegetation quantity decreases. The bare soil index will increase when the bare soil openness degrees of ground increases (Joshi et al. 2005).

The relationship between forest canopy density, tree stand density, basal area and total carbon stock in agroforestry practices

Our results indicate that the relationship between FCD and tree stand density was moderate with an $r$ value closer to 1 (Figure 5, Table 2). This result was in accordance with the report of $\mathrm{Wu}$ and Strahler (1994) that tree stand density estimation could be conducted by using remote sensing including FCD. Furthermore, the FCD value had a strong correlation with the tree stand density (Muhammad et al. 2014; Tohir et al. 2014). These findings suggest that in agroforestry landscape, FCD can be an alternative way to estimate tree stand density in the field, although the accuracy still needs to be improved.

Individually, basal area correlates with tree volume, biomass as well as the width of tree canopy. In this research, basal area was measured by the trained members of local communities. The $\mathrm{R}^{2}$ value showed that predictor variable (FCD) affected $3.36 \%$ of basal area. The relationship between FCD and the basal area was low with an $r$ value far from 1 (Figure 7, Table 2). This result might be due to several factors. Firstly, the difference between the time of imageries captured and the time of field measurement. The imageries were captured from Earthexplorer.usgs.gov in 2014, while the field data were collected throughout 2016 and 2017. It was not possible to clearly capture the imageries in 2015 due to the forest fire catastrophe in Indonesia as the smoke covered the research sites. In 2016, there was damage in the thermal sensor of the satellite. As the data were first collected in 2014, it was possible that vegetations were growing, or otherwise, land clearing and forest conversion occurred during the time gap. Secondly, although FCD allows for the calculation of vegetation index, thermal index, shadow index, and bare soil index, but it still has limitations. For example, it could not very well capture in multilayers canopy such as in agroforestry landscape.

In this study, there was a correlation between tree stand density and FCD $(r=61.4 \%)$. The FCD was able to predict tree stand density with an $\mathrm{R}^{2}$ of $37.7 \%$. In the previous study, the correlation between total carbon stock with tree stand density was $27.3 \%$ (p-val<0.1). These findings imply that it is possible to predict total carbon stock using FCD value.

\section{Model implications}

The results of this study suggest that prediction model using FCD can be used as a new method to estimate tree stand density in agroforestry landscape. This research resulted in a total carbon stock that differs significantly $(\mathrm{p}<0.1)$ depending on total individuals per ha or tree stand density and the correlation was $27.3 \%$ (Table 2). This study, however, resulted in the correlation between the FCD and the tree density of $61.4 \%$, implying that we could use the regression model to estimate total carbon stock using FCD value.

There was no heteroscedasticity found in term of tree stand density. The validation test indicated that the model estimation of total carbon stock obtained by using FCD had reliability of $25.8 \%$ (Table 4 ). Based on the total carbon stock model resulted, the FCD predicted total carbon by using the total carbon model $(\mathrm{Mg} \mathrm{C} / \mathrm{ha})=13.005+0.826$ FCD. We found a higher FCD in this study, indicating a higher total carbon stock in these agroforestry lands. The correlation between carbon stock and canopy density has been reported by $\mathrm{Xu} \mathrm{L}$ et al. (2018) that the importance factors for estimating carbon stock decreased respectively: canopy density $(76.39 \%)$, average age (47.25\%), litter thickness (21.93\%), forest type (19.52\%), altitude $(18.95 \%)$, land use type (16.67\%), age group (15.46\%), vegetation coverage $(14.83 \%)$. This means that canopy density is the most determinant factor than the other factors for estimating carbon stocks.

\section{The relationship between tree architecture profile and carbon stock}

We found that the number of individuals increased along with the increasing value of FCD, except for plot 29 in Merabu Village. A higher individual number also means a higher FCD value and higher density. The coefficient correlation (r) between FCD and tree density was $80.8 \%$ (Figure 12a). The coefficient correlation (r) between canopy closure and carbon stock was $40.4 \%$ (Figure 12b). These findings suggest that in carbon monitoring activities, we can estimate carbon stocks using canopy closure measurement in which a denser canopy closure reflects a higher carbon stock.

In conclusion, we showed that the FCD can be used as a new method to estimate tree density and total carbon stock cheaply, efficiently and accurately in an effort to support carbon stock assessment in agroforestry practices. In 
assessment and monitoring activities, carbon stock can also be estimated using canopy closure measurement.

\section{ACKNOWLEDGEMENTS}

This research was funded by DFC 13-08 KU (DANIDA Fellowship Center), Denmark, and Directorate for Research and Innovation IPB University (Bogor Agricultural University). Acknowledgements are also expressed to the villagers of Birang Village and Merabu Village, the Nature Conservancy (TNC) Program Indonesia and Yayasan Komunitas Belajar Indonesia (YAKOBI) for facilitating the field works.

\section{REFERENCES}

Ardiansyah M, Rosalina U, Boer R. 2005. Estimasi biomassa dan stok karbon atas permukaan dengan menggunakan integrasi teknologi penginderaan jauh dan sistem informasi geografi. IPB Press, Bogor. [Indonesian]

Baynes J. 2007. Using FCD Mapper software and Landsat images to assess forest canopy density in landscapes in Australia and the Philippines. Annal Trop Res 29 (1): 9-20.

Bottcher H, Eisbrenner K, Fritz S, Kindermann G, Kraxner F, McCallum I, Obersteiner M. 2009. An assessment of monitoring requirements and costs of 'Reduced Emissions from Deforestation and Degradation. Carbon Balance Manag 4: 7. DOI: 10.1186/1750-0680-4-7

Boyd DS, Danson FM. 2005. Satellite remote sensing of forest resources: three decades of research development. Prog Phys Geogr 29: 1-26.

Boyd DS, Foody GM, Ripple WJ. 2002. Evaluation of approaches for forest cover estimation in the Pacific Northwest, USA, using remote sensing. Appl Geogr 22: 375-392.

Budiharta S, Meijaard E, Erskine PD, Rondinini C, Pacifici M, Wilson KA. 2014. Restoring degraded tropical forests for carbon and biodiversity. Environ Res Lett 9: 114020. DOI: 10.1088/17489326/9/11/114020.

Budiharta S, Slik F, Raes N, Meijaard E, Erskine PD, Wilson KA. 2014 Estimating the aboveground biomass of Bornean forest. Biotropica 46: 507-511.

Budiharta S, Meijaard E, Wells JA, Abram NK, Wilson KA. 2016. Enhancing feasibility: Incorporating a socio-ecological systems framework into restoration planning. Environ Sci Policy 64: 83-92.

Crow TR, Schlaegel BE. 1988. A guide to using regression equations for estimating tree biomass. North J Appl For 5: 15- 22.

De Fries R, Achard F, Brown S, Herold M, Murdiyarso D, Schlamadinger B, de Souza JrC. 2007. Earth observations for estimating greenhouse gas emissions from deforestation in developing countries. Environ Sci Policy 10 (4): 385-394.

De Fries R, Hansen M, Steininger M, Dubayah R, Sohlberg R, Townshend J, 1997. Subpixel forest cover in central Africa from multisensor, multitemporal data. Remote Sensing Environ 60: 228246.

Department of Forestry. 1992. Manual Kehutanan. Departemen Kehutanan Republik Indonesia, Jakarta, Indonesia. [Indonesian]

Dorren LK, Maier AB, Seijmonsbergen AC. 2003. Improved Landsatbased forest mapping in steep mountainous terrain using object-based classification. For Ecol Manag 183: 31-46.

Duro DC, Coops NC, Wulder MA, Han T. 2007. Development of a large area biodiversity monitoring system driven by remote sensing. Prog Phys Geogr 31: 235-260.

Ford JP, Casey DJ. 1988. Shuttle radar mapping with diverse incidence angles in the rainforest of Borneo. Intl J Remote Sens 9: 927-943.

Gao X, Huete AR, Ni W, Miura T. 2000. Optical-biophysical relationships of vegetation spectra without background contamination. Remote Sens Environ 74 (3): 609-620.

Gong P, Miller JR, Spanner M. 1994. Forest canopy closure from classification and spectral unmixing of scene components-multisensor evaluation of an open canopy. IEEE Trans Geosci Remote Sens 32 (5): 1067-1080.
Goetz S, Baccini A, Laporte N, Johns T, Walker W, Kellndorfer J, Houghton R, Sun M. 2009. Mapping and monitoring carbon stocks with satellite observations: a comparison of methods. Carbon Balance Manag 4: 2. DOI: 10.1186/1750-0680-4-2

Hahn JT. 1984. Tree volume and biomass equations for the Lake States USDA FS Res. Pap. NC-250. St. Paul, MN.

Intergovernmental Panel on Climate Change (IPCC). 2006. Guidelines for National Greenhouse Gas Inventories. Institute for Global Environmental Strategies (IGES), Hayama, Japan.

Iverson LR, Cook EA, Graham RL. 1989. A technique for extrapolating and validating forest cover across large regions: calibrating AVHRR data with TM data. Intl J Remote Sens 10: 1805-1812.

Joshi C, De Leeuw J, Skidmore AK. 2005. Remotely sensed estimation of forest canopy density: A comparison of the performance of four methods. Intl J Appl Earth Observ Geoinf 8 (2): 84-95.

Joshi C, Leeuw JD, Skidmore AK, Duren ICV, Oosten HV 2006. Remotely sensed estimation of forest canopy density: a comparison of the performance of four methods. International $\mathrm{J}$ Appl Earth Observ Geoinf 8: 84-95.

Khairiah RN, Prasetyo LB, Setiawan Y, Kosmaryandi N. 2016. Monitoring model of payment for environmental service (PES) implementation in Cidanau Watershed with stand density approach. Procedia Environ Sci 33: 269-278.

Mon MS, Kajisa T, Mizoue N, Yoshida S. 2010. Monitoring deforestation and forest degradation the Bago mountain area, Myanmar using FCD Mapper. J Rr Hann 15: 63.

Muhammad A, Prasetyo LB, Kartono AP. 2014. Pemetaan perubahan forest canopy density di KPH Kuningan. Seminar Nasional Penginderaan Jauh 2014 "Deteksi Parameter Geobiofisik dan Diseminasi Penginderaan Jauh". [Indonesian]

Ohmann LF, Grigal DF. 1985. Plant species biomass estimates for 13 upland community types of northeastern Minnesota. USDA FS Res Bull RB-NC-88, St. Paul, MN.

Panta M, Kim M. 2006. Spatio-temporal dynamic alteration of forest canopy density-based on-site associated factors: view from tropical forest of Nepal. Korean J Remote Sens 22 (5): 1-11.

Perala DA, Alban DH. 1994. Allometric biomass estimations for Aspendominated ecosystems in the Upper Great Lakes. USDA FS Res Pap NC-134.

Prasad PRC, Nagabhatla N, Reddy CS, Gupta S, Rajan KS, Raza SH, Dutt CBS. 2009. Assessing forest canopy closure in a geospatial medium to address management concerns for tropical islands southeast Asia. Environ Monit Assess DOI:10.1007/s10661-008-0717-4.

Prince SD. 1987. Measurement of canopy interception of solar radiation by stands of trees in sparsely wooded savanna (Sudan). Intl J Remote Sens 8: 1747-1766.

Regulation of Indonesia Ministry of Environmental and Forestry Number P.70/MENLHK/SETJEN/KUM.1/12/2017. 2017. Reducing Emissions from Deforestation and Forest Degradation, Role of Conservation, Sustainable Management of Forest and Enhancement of Forest Carbon Stocks. Ministry of Environmental and Forestry Republic of Indonesia, Jakarta, Indonesia. [Indonesian]

Rikimaru A. 1996. Landsat TM data processing guide for forest canopy density mapping and monitoring model. In: International Tropical Timber Organization (ITTO) workshop on utilization of remote sensing in site assessment and planning for rehabilitation of loggedover forest, Bangkok, Thailand.

Rikimaru A, Miyatake S. 1997. Development of forest canopy density mapping and monitoring model using indices of vegetation, bare soil and shadow. https://www.geospatialworld.net/article/development-offorest-canopy-density-mapping-and-monitoring-model-using-indicesof-vegetation-bare-soil-and-shadow/

Rikimaru A, Roy PS, Miyatake S. 2002. Tropical forest cover density mapping. Trop Ecol 43 (1): 39-47.

Rosadi D. 2011. Analisis Ekonometrika \& Runtun Waktu Terapan dengan R. Andi Offset, Yogyakarta, Indonesia. [Indonesian]

Soerianegara I. 1996. Ekologi, Ekologisme dan Pengelolaan Sumberdaya Hutan. Fakultas Kehutanan IPB, Bogor. [Indonesian]

Souza JC, Firestone CL, Silva LM, Roberts D. 2003. Mapping forest degradation in the Eastern Amazon from SPOT-4 through spectral mixture models. Remote Sens Environ 87: 494-506.

Strand H, Höft R, Stritthold J, Miles L, Horning N, Fosnight E, Turner W. 2007. Sourcebook on Remote Sensing and Biodiversity Indicators. CBD, Montreal, Canada, USA. 
Tiwari AK, Mehta JS, Goel OP, Singh JS, 1986. Geo-forestry of landslide-affected areas in a part of central Himalaya. Environ Conserv 13: 299-309.

Tohir NR, Prasetyo LB, Kartono AP. 2014. Pemetaan perubahan kerapatan kanopi hutan di hutan rakyat, Kabupaten Kuningan, Jawa Barat. Seminar Nasional Penginderaan Jauh 2014 "Deteksi Parameter Geobiofisik dan Diseminasi Penginderaan Jauh". [Indonesian]

Turner W, Spector S, Gardiner N, Fladeland M, Sterling E, Steininger M. 2003. Remote sensing for biodiversity science and conservation. Trends Ecol Evol 18: 306-314.

Walpole RE. 1992. Introduction to Statistics. 3rd ed. PT Gramedia Pustaka Utama, Jakarta, Indonesia. [Indonesian]
Wibowo A, Ratnasari D, Sukojo BM, Harianto T, Djajadih YS. 2010. Ekstraksi kandungan air kanopi daun tanaman padi dengan data hyperspectral. Geomatika 1 (16): 21-31.

Wu Y, Strahler AH. 1994. Remote estimation of crown size, stand density, and biomass on the Oregon Transect. Ecol Soc Am 4 (2): 299-312.

Xu L, Shi Y, Fang H, Zhou G, Xu X, Zhou Y, Tao J, Ji B, Xu J Li C, Chen L. 2018. Vegetation carbon stocks driven by canopy density and forest age in subtropical forest ecosystems. Sci Tot Environ 631-632: 619-626.

Zhu Z. Evans DL. 1994. US forest types and predicted percent forest cover from AVHRR data. Photogrammetric Eng Remote Sens 60: 525-553. 